\title{
Vegetation Responses to Roller Chopping and Buffelgrass Seeding in Argentina
}

\author{
Lisandro J. Blanco, ${ }^{1}$ Carlos A. Ferrando, ${ }^{2}$ Fernando N. Biurrun, ${ }^{3}$ \\ Enrique L. Orionte, ${ }^{4}$ Pedro Namur, ${ }^{5}$ Dario J. Recalde, ${ }^{6}$ and \\ German D. Berone
}

\begin{abstract}
Authors are ${ }^{1}$ Graduate Student and ${ }^{2}$ Range Scientist, La Rioja Experimental Station, Instituto Nacional de Tecnología Agropecuaria (INTA), CC 26, 5380 Chamical, La Rioja, Argentina; ${ }^{3}$ Biologist, Universidad Nacional de La Rioja-Sede Chamical, Castro Barros 557, 5380 Chamical, La Rioja, Argentina; and ${ }^{4}$ Range Ecologist, ${ }^{5}$ Research Forage Scientist, and

${ }^{6,7}$ Graduate Students, La Rioja Experimental Station, Instituto Nacional de Tecnología Agropecuaria (INTA), CC 26,
\end{abstract} 5380 Chamical, La Rioja, Argentina.

\begin{abstract}
T-4464 Buffelgrass (Cenchrus ciliaris L.) is an introduced grass used extensively for restoring forage capacity of denuded shrublands in the arid Chaco region in central western Argentina. Currently, the technique of roller chopping and simultaneous buffelgrass seeding is widespread, but information is lacking about its effects on forage production and other vegetation attributes at the regional scale. The purpose of our study was to compare grass yield; vegetation cover and density; and species richness, diversity, and evenness, between roller chopping and simultaneous buffelgrass seeding with nontreated native degraded shrublands. Eight sites, including matched pairs of treated and nontreated areas, were studied. Grass yield, total perennial grass cover, and total perennial grass density were higher $(P<0.05)$ on treated areas. Increase in grass yield on treated areas compared with nontreated areas was related to the increase in total perennial grass cover due to added buffelgrass cover $\left(r^{2}=0.79\right)$. Shrub cover was lower $(P<0.05)$ on treated areas, but shrub density was not different between treatments $(P>0.05)$. Nonsignificant differences $(P>0.05)$ between treated and nontreated areas were detected in tree cover and density, species number, diversity index, and evenness. The results of this study indicate that, in the short term, roller chopping and simultaneous buffelgrass seeding produces rapid increases in grass cover and grass yield, and a drastic reduction in shrub cover without affecting species diversity on degraded shrublands of the arid Chaco region of Argentina.
\end{abstract}

\section{Resumen}

El buffel T-4464 (Cenchrus ciliaris L.) es un pasto introducido, utilizado para restaurar la capacidad forrajera de matorrales degradados en el sector centro-occidental de la región del Chaco árido, Argentina. En la actualidad el rolado y siembra simultánea de buffelgrass está ampliamente difundido en la región. Sin embargo, se carece de información a nivel regional, relacionada con los efectos de la aplicación de esta técnica sobre la producción de gramíneas y otros atributos de la vegetación. El objetivo de nuestro estudio fue comparar diferentes atributos de la vegetación entre áreas roladas y sembradas con pasto buffel y matorrales degradados (testigo). Para ello se seleccionaron ocho áreas roladas y sembradas, y ocho áreas testigo adyacentes. Se evaluó la producción de gramíneas, la cobertura y densidad de la vegetación, y el número de especies, diversidad y equitatividad. La producción de gramíneas, la cobertura de gramíneas perennes totales, y la densidad de gramíneas perennes totales fue mayor $(P<0.05)$ en las áreas sometidas a rolado y siembra. La mayor producción de gramíneas en las áreas roladas y sembradas respecto a las testigo, se relacionó positivamente con la cobertura de pasto buffel $\left(r^{2}=0.79\right)$. La cobertura de arbustos fue menor $(P<0.05)$, en áreas roladas y sembradas. Sin embargo, no se detectaron diferencias $(P>0.05)$ entre áreas en la densidad de arbustos. Tampoco se detectaron diferencias $(P>0.05)$ en la densidad y cobertura de árboles, el número de especies, el índice de diversidad y la equitatividad. Los resultados de este estudio indican que, el rolado y siembra simultánea de pasto buffel aplicado en matorrales degradados de la región del Chaco árido de Argentina produce, en el corto período, a) un rápido incremento en la cobertura y producción de gramíneas, y b) una drástica reducción en la cobertura de arbustos sin afectar la diversidad de especies.

Key Words: grass seeding, grass yield, vegetation attributes, Argentinean semiarid shrublands, Chaco arido region

\section{INTRODUCTION}

The arid Chaco region of Argentina covers approximately 10 million ha in eastern La Rioja and San Juan, western Córdoba,

Funding was provided by the Instituto Nacional de Tecnología Agropecuaria (INTA).

Correspondence: Lisandro J. Blanco, La Rioja Experimental Station, Instituto Nacional de Tecnología Agropecuaria (INTA), CC 26, 5380 Chamical, La Rioja, Argentina. Email: becarioja@correo.inta.gov.ar

Manuscript received 21 September 2003; manuscript accepted 13 October 2004. northern San Luis, and southern Santiago del Estero and Catamarca provinces (Morello et al. 1985). Native vegetation communities of this region provide forage for livestock and wildlife. Cattle production, based on cow-calf operations, is the principal source of agricultural income (Ferrando and Namur 1984). Native grass species are the main forage source for cattle (Anderson et al. 1980; Ferrando et al. 2001). Losses of native grass species and subsequent carrying capacity, and increased soil erosion due to overgrazing are topics of major concern (Cabido et al. 1994). Grass biomass reduction and 


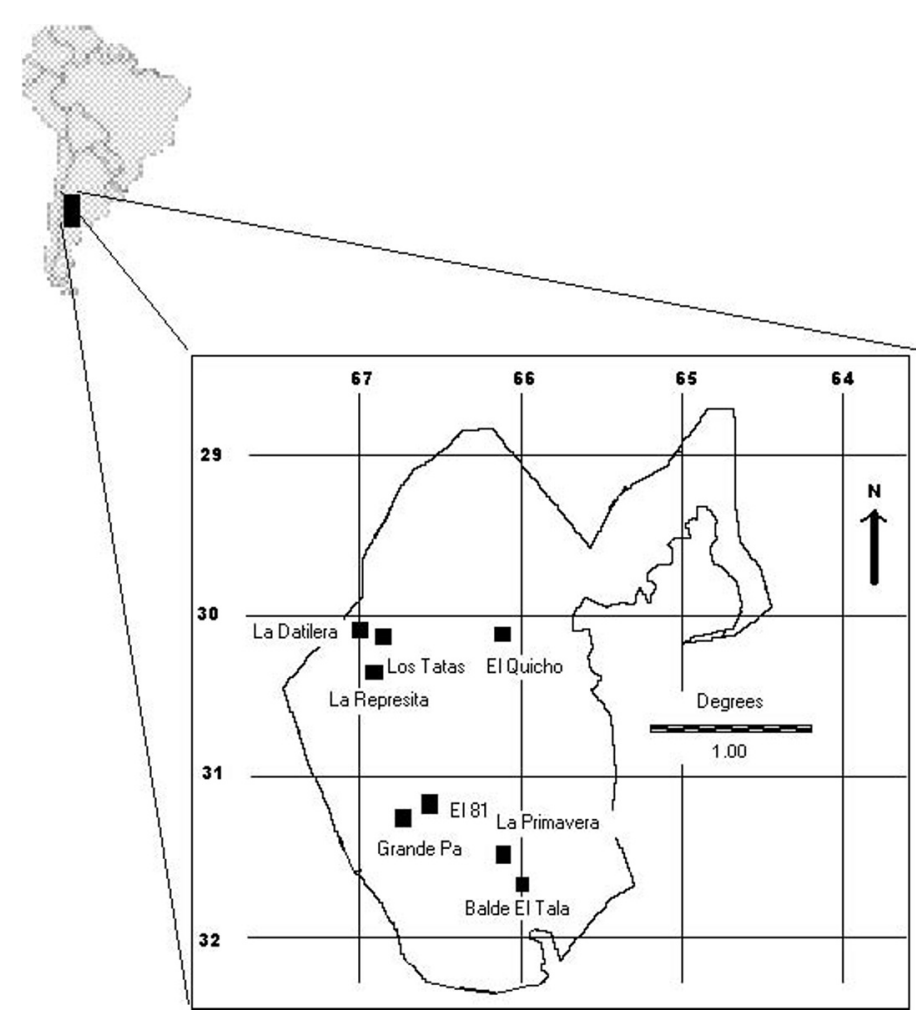

Figure 1. Map of the arid Chaco region. Squares indicate geographic location of the 8 sites under study.

botanical composition changes have induced quantitative and qualitative forage loss (Anderson et al. 1980).

T-4464 buffelgrass (Cencrhus ciliaris L.) seeding is becoming a regional strategy for rapid restoration of grass cover and grazing capacity of degraded areas. Buffelgrass is a droughttolerant perennial species that establishes rapidly and produces palatable forage (Namur 1985; Martin-R et al. 1995). In addition, buffelgrass seeding is effective on areas with a high percentage of bare soil, reduced native seed banks, and low soil nutrient contents (Ibarra-F et al. 1995).

It is regionally proposed that complementary buffelgrass pastures (usually $10 \%$ of total ranch surface) grazed during spring and summer help increase carrying capacity and animal production. Direct increases in forage production of denuded areas, indirect increases in forage production of the $90 \%$ of the remaining rangeland due to deferred use, improved herd care, and management during calving and breeding periods are the main reasons for increased carrying capacity and animal production (Namur et al. 1998).

Earlier local buffelgrass establishment practices included shrub hand grubbing and clearing, disk plowing, and hand sowing. Because these earlier practices were expensive and time consuming, they have been replaced recently by direct sowing using a common roller chopper with an attached seeding device.

Roller chopping is used for shrub control (Tanner et al. 1988) and range improvement (Yarlett 1965). In general, topremoval methods are used to stimulate the release of native forage with minimal soil disturbance. However, these methods may have relatively short-term effects because of the regrowth potential and competition of many woody species (Scifres et al. 1985). Gómez et al. (1998) reported that woody species cover increased from $16 \%$ to $28 \%$ after 4 years of roller chopping without seeding in the arid Chaco region, and concluded that periodic shrub removal would be necessary to maintain high native forage production levels.

Mechanical brush manipulation plus buffelgrass seeding has been a commonly used practice throughout arid and semiarid regions. On the Rio Grande Plains, Gonzalez and Dodd (1979) found that mechanical manipulation of brush followed by grass seeding decreased or retarded brush growth and increased forage production 3- to 4-fold, and that the major portion of forage increase was attributed to buffelgrass. In the arid Chaco, Aguilera and Steinaker (2001) found significant grass forage production increment mainly related to an increase of native grass production when applying roller chopping plus simultaneous buffelgrass seeding. In addition, the greatest response was obtained in denuded areas of poor range condition. They also found low mortality of woody species, except for algarrobo negro (Prosopis flexuosa DC.), tintitaco (Prosopis torquata [Cav. ex Lag.] DC.), and lata (Mimozyganthus carinatus [Griseb.] Burkart), even though these species are crown sprouters. However, these results are limited to a single site.

Lack of information regarding the long- and short-term effects of roller chopping and simultaneous buffelgrass seeding on forage and vegetation parameters at the regional scale led us to initiate this project in 1999. To evaluate short-term effects, the purpose of this study was to compare grass yield, vegetative cover and density, species richness, species diversity, and evenness between rolling and simultaneous buffelgrass seeding treatment and nontreated native degraded shrublands of the arid Chaco region.

\section{MATERIALS AND METHODS}

\section{Study Area}

This study was conducted in La Rioja Province, within the arid Chaco region, located in central western Argentina (lat $29^{\circ}$ $32^{\circ} \mathrm{S}$, long $65^{\circ}-67^{\circ} \mathrm{W}$ ) (Fig. 1). The climate is semiarid, characterized by hot summers and mild winters. January has the highest average temperature $\left(26^{\circ} \mathrm{C}\right)$, whereas July has the lowest $\left(11^{\circ} \mathrm{C}\right)$ (Morello et al. 1985). The frost-free period is 289 days from 19 August to 4 June (Bazán 1993). Long-term average annual precipitation ranges between $450 \mathrm{~mm}$ to the east and $200 \mathrm{~mm}$ to the west, with $80 \%$ falling between November and March (Díaz Nieva et al. 1994). According to Gómez et al. (1993), soils in the region are aridisols and entisols, with local texture variations.

Current vegetation is characterized by a continuous shrubland with isolated trees and patches of grass (Morello et al. 1985). Dominant woody plant genera include Larrea, Aspidosperma, Prosopis, and Mimozyganthus. Dominant grass genera are Pappophorum, Trichloris, Setaria, Aristida, Chloris, and Neobouteloua. The growing season generally extends from September to April for woody species. However, grasses grow from November to March, matching the seasonal precipitation distribution (Anderson et al. 1977).

\section{Field Measurements}

Eight sites within degraded shrubland, each including matched pairs of plots (16 plots of 5 ha each) representing nontreated and treated with roller chopping and buffelgrass seeding were 
Table 1. Location, treatment application date, average (1991-2000) growing season (November-March) precipitation, growing season precipitation from treatment application to evaluation date, soil texture, and buffelgrass seeding rate on 8 study sites.

\begin{tabular}{|c|c|c|c|c|c|c|c|c|}
\hline \multirow[b]{2}{*}{ Description } & \multicolumn{4}{|c|}{ 1997-1998 treated sites } & \multicolumn{4}{|c|}{ 1998-1999 treated sites } \\
\hline & La Represita & Los Tatas & Balde El Tala & La Primavera & El Quicho & La Datilera & Grande $\mathrm{Pa}$ & El 81 \\
\hline Longitude (W) & $66^{\circ} 51^{\prime} 42^{\prime \prime}$ & $66^{\circ} 50^{\prime} 03^{\prime \prime}$ & $66^{\circ} 00^{\prime} 14^{\prime \prime}$ & $66^{\circ} 09^{\prime} 59^{\prime \prime}$ & $66^{\circ} 06^{\prime} 11^{\prime \prime}$ & $66^{\circ} 58^{\prime} 03^{\prime \prime}$ & $66^{\circ} 41^{\prime} 36^{\prime \prime}$ & $66^{\circ} 34^{\prime} 57^{\prime \prime}$ \\
\hline Latitude (S) & $30^{\circ} 19^{\prime} 15^{\prime \prime}$ & $30^{\circ} 03^{\prime} 06^{\prime \prime}$ & $31^{\circ} 44^{\prime} 50^{\prime \prime}$ & $31^{\circ} 35^{\prime} 21^{\prime \prime}$ & $30^{\circ} 04^{\prime} 12^{\prime \prime}$ & $30^{\circ} 05^{\prime} 13^{\prime \prime}$ & $31^{\circ} 18^{\prime} 50^{\prime \prime}$ & $31^{\circ} 16^{\prime} 44^{\prime \prime}$ \\
\hline Treatment application date ${ }^{1}$ & January 1998 & January 1998 & January 1998 & February 1998 & November 1998 & November 1998 & December 1998 & January 1999 \\
\hline \multicolumn{9}{|l|}{ Average November-March } \\
\hline precipitation (mm) & 275 & 306 & 339 & 361 & 325 & 296 & 240 & 314 \\
\hline \multicolumn{9}{|l|}{ November 1997-March 1998} \\
\hline precipitation $(\mathrm{mm})^{2}$ & 296 & & 368 & 307 & - & - & - & - \\
\hline \multicolumn{9}{|l|}{ November 1998-March 1999} \\
\hline precipitation (mm) & 234 & 279 & 349 & 347 & 361 & 264 & 187 & 355 \\
\hline \multicolumn{9}{|l|}{ November 1999-March 2000} \\
\hline precipitation (mm) & 383 & 263 & 692 & 404 & 506 & 321 & 313 & 418 \\
\hline Soil texture ${ }^{3}$ & $\begin{array}{l}\text { Gravelly, } \\
\text { Ioamy sand }\end{array}$ & Loamy clay & Loamy sand & Loamy sand & Sandy loam & $\begin{array}{l}\text { Gravelly, } \\
\text { loamy sand }\end{array}$ & Loamy sand & $\begin{array}{l}\text { Gravelly, } \\
\text { Ioamy sand }\end{array}$ \\
\hline Seeding rate $(\mathrm{kg} / \mathrm{ha})$ & 6.0 & 6.0 & 4.4 & 5.2 & 7.0 & 5.0 & 3.9 & 7.1 \\
\hline
\end{tabular}

${ }^{1}$ Treatment consisted of roller chopping and simultaneous buffelgrass seeding.

${ }^{2}$ November 1997-March 1998 precipitation data for 1998-1999 treated sites are not presented because they are previous to treatment application.

${ }^{3}$ Extracted from Gómez et al. (1993).

selected. Four sites were treated during the November 1997March 1998 growing season and 4 sites were treated during the November 1998-March 1999 growing season (Table 1). Roller chopping and simultaneous buffelgrass seeding was a 1 -way treatment. The equipment used in the 8 sites consisted of a roller chopper with an attached seeding device pulled at 5.0 to $8.0 \mathrm{~km} / \mathrm{h}$ with a 140 -hp rubber-tired tractor. The roller chopper used was a single 4-mT cylinder, $3.0 \mathrm{~m}$ in length and $1.5 \mathrm{~m}$ in diameter, with $15-\mathrm{cm}$-high blades running parallel to the axis. The seeding device was located in front of the roller chopper and consisted of a drum, $3.0 \mathrm{~m}$ in length and $0.6 \mathrm{~m}$ in diameter, with small holes in the surface.

Geographic location, distinctive site characteristics, treatment application date, and buffelgrass seeding rates on each site are shown in Table 1 . Topography was similar among sites and consisted of flat plains with gentle slopes $(<1 \%)$. Frost-free days and temperatures were similar among sites.

Species number, density, canopy cover, and grass yield on treated and nontreated areas were recorded between April and August 2000. Thus, yield responses were at 2 growing seasons posttreatment for the 1997-1998 treatments and 1 growing season posttreatment for the 1998-1999 treatments. Species number, species density, and species canopy cover of each plot were obtained by using $0.5 \mathrm{~m} \times 1 \mathrm{~m}$ frames. Three 20 - $\mathrm{m}$-long transects per plot were randomly located. Ten frames, every $2 \mathrm{~m}$, were located along each transect (30 frames per area). The canopy-coverage method of Daubenmire (1959) was used to estimate canopy cover and species density. Evenness (Pielou 1966) and diversity indices (Shannon and Weaver 1949) were calculated using species canopy cover data. Growth form classification (Raunkiaer 1934) was used for grouping data in 6 categories: tree (microphanerophytes), shrub (nanophanerophytes), total perennial grass (hemicryptophytes), native perennial grass (total hemicryptophytes minus buffelgrass), annual grass and forb (therophytes), and other life forms (geophytes, chamaephytes, epiphytes, scandent phanerophytes, and succulents). Canopy cover and density for each category were calculated by summing species cover and density data, respectively.

The double-sampling technique (Pechanec and Pickford 1937) was used to estimate total grass yield (native perennial grasses + native annual grasses + buffelgrass). Twenty-five frames measuring $0.5 \mathrm{~m} \times 1 \mathrm{~m}$ were randomly located along a single transect in each plot. Grass yield of each frame was visually estimated. Five frames per plot were clipped at ground level. Grass yield was calculated considering all current year's growth. Clipped material of each frame was oven-dried at $65^{\circ} \mathrm{C}$ for 72 hours. Linear regression equations for each area were calculated using estimated and clipped paired data (Wilm et al. 1949). Grass yield of each plot was obtained by averaging regression data. Number of estimated and clipped frames for calculating the double-sampling equation was according to Blanco and Ferrando (2000).

\section{Statistical Analysis}

Statistical analyses were conducted using the SAS statistical procedures (SAS 1989). Buffelgrass cover and density, category cover and density, evenness, diversity index, and grass yield were analyzed with the $t$ test for matched pairs (treated and nontreated areas). The $t$ tests were separately run for treated sites in 1997-1998 and 1998-1999 growing seasons. $P<0.05$ was established for reporting significant differences. We evaluated the relationship between the difference in grass yield between treated and nontreated areas $(y)$ and buffelgrass cover on treated areas $(x)$ by simple linear regression analysis.

\section{RESULTS AND DISCUSSION}

Growing season precipitation during treatment application was above normal in La Represita (8\%), Balde El Tala (9\%), El Quicho (11\%), and El $81(13 \%)$, and below average in La 
Table 2. Mean $\pm 1 \mathrm{SE}^{1}$ and $P$ value of grass yield $\left(\mathrm{kg} \cdot \mathrm{DM} \cdot \mathrm{ha}^{-1}\right)$, total perennial grass ${ }^{2}$ cover $(\%)$ and total perennial grass density $\left(\mathrm{plants} \cdot \mathrm{m}^{-2}\right)$ on treated and nontreated areas, for the 1997-1998 and 1998-1999 treated sites ${ }^{3}$.

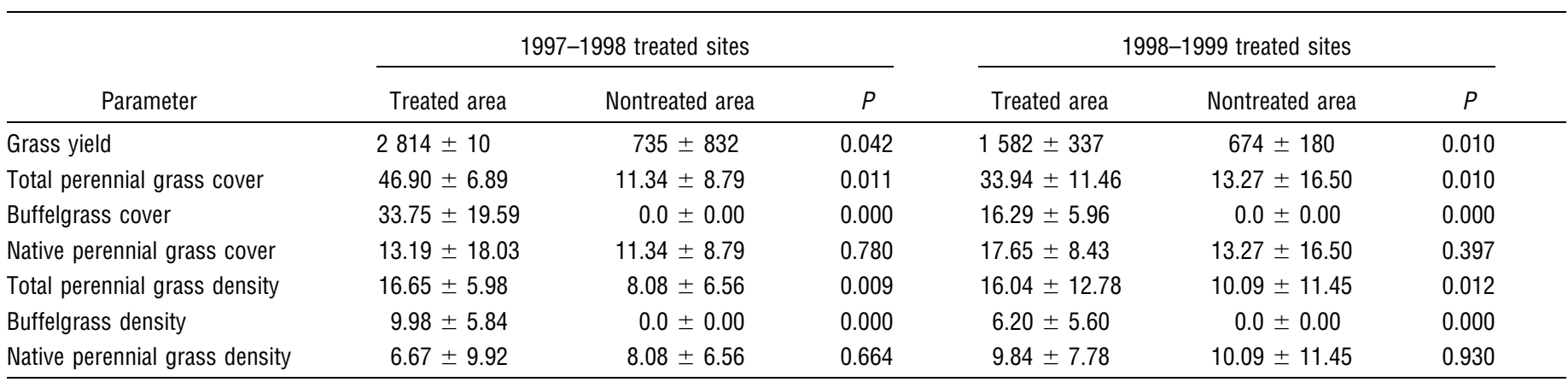

${ }^{1}$ SE indicates standard error; DM, dry matter.

${ }^{2}$ Total perennial grass $=$ buffelgrass + native perennial grass.

${ }^{3}$ All data were collected during the August 1999-April 2000 growing season.

Primavera (15\%), La Datilera (11\%), and Grande Pa (24\%) (Table 1). However, growing season precipitation (1999-2000) prior to the evaluation date was above normal in Balde El Tala (104\%), El Quicho (55\%), El 81 (33\%), Grande Pa (30\%), La Primavera $(12 \%)$, and La Datilera $(8 \%)$; normal in La Represita; and below normal in Los Tatas (14\%).

Grass yield was greater on treated areas than nontreated areas $(P<0.05)$ at both 1 and 2 years posttreatment (Table 2$)$. Total perennial grass (buffelgrass + native perennial grass) cover and density were greater $(P<0.05)$ on treated areas, whereas native perennial grass cover and density were similar $(P>0.05)$ between both areas and appeared independent of the number of growing seasons following treatment application.

Roller chopping and simultaneous buffelgrass seeding treatment produced $282 \%$ and $135 \%$ increases in grass yield for the sites treated in 1997-1998 and 1998-1999, respectively. Even though we did not separate species during clipping, lack of differences in native perennial grass cover between treated and nontreated areas suggests that increases in grass yield were associated with buffelgrass cover. Moreover, we found a strong positive linear relationship $\left(P=0.008 ; r^{2}=0.79\right)$ in grass yield difference between treated and nontreated areas with buffelgrass cover on treated areas.

Treatments that diminish woody species cover generally stimulate the release of native grass cover (Scifres et al 1985). Lack of significant increases in perennial native grass cover due to mechanical manipulation in our study seems to be contradictory to this generalization. Even though our study did not allow us to discriminate the causes for lack of increases in perennial grass cover in treated plots, we suppose that the competitive ability of seeded buffelgrass was the main factor responsible for this.

Gómez et al. (1998) reported that native perennial grass cover increased $53 \%$ after 2 years of roller chopping without seeding in the arid Chaco region. Passera et al. (1992) reported shrub cleared and shrub cleared + native grass sown treatments increased perennial grass cover with respect to control treatment, but did not find significant difference in perennial grass cover between both treatments. However, buffelgrass was not sown in either study.

Aguilera and Steinaker (2001) reported 52\% and 13\% increases in grass yield 15 and 27 months, respectively, after roller chopping and simultaneous buffelgrass seeding treat- ment application. These increases in grass yield are small compared to our findings. They also reported a high native perennial grass cover before treatment application $(42 \%)$, scarce buffelgrass cover $(7.7 \%)$, and a drastic decrease in buffelgrass plant density ( 18.5 to 4.2 buffelgrass plants. $\mathrm{m}^{-2}$ ) between 15 and 27 months after treatment application. Considering the high native perennial grass cover before treatment, it is possible that the reported low increases in grass yield, low buffelgrass cover, and drastic decreases in buffelgrass plant densities could be associated with native perennial grass competition. However, it is important to consider that the Aguilera and Steinaker (2001) study area was located at the coldest southern extreme of the thermal gradient of the arid Chaco region. According to Ibarra-F et al. (1995), mean minimum temperature in the coldest month is an important factor associated with T-4464 buffelgrass survival success. Temperature variations could be an important factor associated with differences between their findings and ours.

Gonzalez and Dodd (1979) reported that mechanical shrub control (root-plowing and front-end stacking) with grass seeding (buffelgrass and native species) increased forage production more than $170 \%$ compared with an undisturbed control area in the Rio Grande plains (Texas). Buffelgrass contributed between $53 \%$ and $73 \%$ of total herbaceous production in treated plots. They also reported invasion of buffelgrass plants on all treatments and suggest that buffelgrass responds faster to rainfall and has greater competitive ability than native grass species.

Shrub cover on treated areas was lower $(P=0.043)$ for treated sites in 1998-1999 treatments and marginally lower $(P=0.062)$ for treated sites in 1997-1998 treatments than those on nontreated areas (Table 3). Roller chopping and simultaneous buffelgrass seeding treatment produced $65 \%$ reduction in shrub cover. Similar results are reported by Aguilera and Steinaker (2001), who found a $63 \%$ reduction in woody species (trees and shrubs) cover 15 months after roller chopping and simultaneous buffelgrass seeding treatment application. On a flatwood range of South Florida, Tanner et al. (1988) reported 57\% reduction in shrub cover 12 months after roller chopping without seeding. Even though tree cover on treated areas was not statistically different $(P>0.05)$ from that on nontreated areas, there was a trend that tree cover was greater in nontreated areas. 
Table 3. Mean $\pm 1 \mathrm{SE}^{1}$ and $P$ value of annual grass and forb, shrub, tree, and other life forms covers (\%) and densities (plants. $\mathrm{m}^{-2}$ ) on treated and nontreated areas, for the 1997-1998 and 1998-1999 treated sites.

\begin{tabular}{|c|c|c|c|c|c|c|c|}
\hline \multirow[b]{2}{*}{ Category } & \multirow[b]{2}{*}{ Parameter } & \multicolumn{3}{|c|}{ 1997-1998 treated sites } & \multicolumn{3}{|c|}{ 1998-1999 treated sites } \\
\hline & & Treated area & Nontreated area & $P$ & Treated area & Nontreated area & $P$ \\
\hline \multirow[t]{2}{*}{ Shrub } & Cover & $12.13 \pm 4.59$ & $32.48 \pm 17.27$ & 0.062 & $15.50 \pm 9.35$ & $50.06 \pm 19.56$ & 0.043 \\
\hline & Density & $1.58 \pm 0.68$ & $0.93 \pm 0.54$ & 0.092 & $1.50 \pm 0.65$ & $1.22 \pm 0.73$ & 0.563 \\
\hline \multirow[t]{2}{*}{ Tree } & Cover & $4.44 \pm 5.13$ & $20.00 \pm 12.10$ & 0.153 & $3.15 \pm 3.76$ & $12.59 \pm 6.70$ & 0.154 \\
\hline & Density & $0.08 \pm 0.10$ & $0.07 \pm 0.06$ & 0.841 & $0.07 \pm 0.06$ & $0.12 \pm 0.08$ & 0.518 \\
\hline \multirow[t]{2}{*}{ Annual grass and forb } & Cover & $4.71 \pm 8.82$ & $8.19 \pm 15.88$ & 0.397 & $7.46 \pm 11.92$ & $8.86 \pm 17.44$ & 0.672 \\
\hline & Density & $13.63 \pm 23.84$ & $18.22 \pm 32.17$ & 0.361 & $8.77 \pm 16.55$ & $14.89 \pm 29.37$ & 0.407 \\
\hline \multirow[t]{2}{*}{ Other life forms } & Cover & $0.46 \pm 0.32$ & $2.83 \pm 5.18$ & 0.412 & $0.42 \pm 0.39$ & $2.56 \pm 2.96$ & 0.196 \\
\hline & Density & $1.73 \pm 1.70$ & $0.75 \pm 0.87$ & 0.497 & $0.32 \pm 0.46$ & $0.85 \pm 1.33$ & 0.322 \\
\hline
\end{tabular}

${ }^{1} \mathrm{SE}$ indicates standard error.

Tree and shrub densities on treated areas were no different $(P>0.05)$ from those on nontreated areas (Table 3). Similar shrub and tree densities on both areas lead us to hypothesize that the treatment did not cause mortality, or that mortality was compensated for by germination. Although we did not quantify seedling recruitment, we observed much basal sprouting of damaged plants and few new shrub and tree seedlings. Aguilera and Steinaker (2001) reported $48 \%$ and $63 \%$ mortality of trees 15 and 27 months after treatment application, respectively. Although their results seem to contradict our findings, we did not measure tree and shrub mortality, and therefore direct comparisons are not possible.

Cover and density of annual grass, forb, and other life forms were not different $(P>0.05)$ between treated and nontreated areas (Table 3). According to Schott and Pieper (1987), in shrub-dominated communities of New Mexico, an annual community commonly becomes prevalent following a catastrophic disturbance such as fire or chaining. Lack of increase in annual grass and forb density and cover values in our study probably would be related to buffelgrass incorporation. In addition, it is possible that the roller chopping action caused less significant disturbances than fire or chaining treatments.

The nonsignificant differences found in species number, Shannon-Weaver diversity index, and evenness $(P>0.05)$ between treated and nontreated areas (Table 4) suggest that even though roller chopping and simultaneous buffelgrass seeding treatment modified shrub, tree, and perennial grass canopy cover, species diversity was not modified. Fulbright (1996) indicated that treatments such as disking and roller chopping might result in posttreatment plant communities that are temporarily greater in species richness and diversity than in nontreated communities. Bozzo et al. (1992) found that forb species richness was greater during the first year after disking than in a nontreated area in southern Texas. For the same area, Fulbright and Beasom (1987) reported that species richness of thorn-scrub that reestablished following roller chopping or repeated shredding did not differ from untreated rangeland in southern Texas.

\section{CONCLUSION}

The results of this study indicate that roller chopping and simultaneous buffelgrass seeding produces rapid increases in grass cover and yield in the first and second growing seasons following treatment. However, drastic reduction in shrub cover from the mechanical treatment did not change species diversity on degraded shrublands of the arid Chaco region of Argentina. Increases in grass yield were mainly related to increases in buffelgrass cover and not native perennial grasses. Because this study considered only short-term effects, studies dealing with long-term effects are needed for proper management recommendations.

\section{ACKNOWLEDGEMENTS}

Thanks go to Dr Manuel O. Aguilera and Dr David L. Anderson for reviewing this manuscript.

\section{LITERATURE CITED}

Aguilera, M. O., and D. F. Steinaker. 2001. Rolado y Siembra en arbustales semiáridos de San Luís (in Spanish). In: J. Panigatti, D. Buschiazzo, and H. Marelli [eds.]. Siembra directa II. Buenos Aires, Argentina: Ediciones INTA. p 289-302.

Anderson, D. L., E. L. Orionte, J. C. Vera, and P. Namur. 1977. Utilización invernal de gramíneas estivales en un establecimiento ganadero de Los Llanos de La

Table 4. Mean $\pm 1 \mathrm{SE}^{1}$ and $P$ value of species number, Shannon-Weaver diversity index, and evenness on treated and nontreated areas, for the 1997-1998 and 1998-1999 treated sites.

\begin{tabular}{|c|c|c|c|c|c|c|}
\hline \multirow[b]{2}{*}{ Parameter } & \multicolumn{3}{|c|}{ 1997-1998 treated sites } & \multicolumn{3}{|c|}{ 1998-1999 treated sites } \\
\hline & Treated area & Nontreated area & $P$ & Treated area & Nontreated area & $P$ \\
\hline Species number & $12.42 \pm 2.17$ & $12.75 \pm 5.09$ & 0.883 & $11.75 \pm 3.66$ & $9.33 \pm 2.71$ & 0.257 \\
\hline Shannon-Weaver diversity index & $1.50 \pm 0.55$ & $1.58 \pm 0.37$ & 0.773 & $1.61 \pm 0.30$ & $1.38 \pm 0.32$ & 0.368 \\
\hline Evennesss & $0.61 \pm 0.18$ & $0.68 \pm 0.02$ & 0.488 & $0.71 \pm 0.03$ & $0.67 \pm 0.10$ & 0.476 \\
\hline
\end{tabular}

${ }^{1}$ SE indicates standard error. 
Rioja. (in Spanish). Revista de Información sobre Investigación y Desarrollo Agropecuario (IDIA). 35:321-329.

Anderson, D. L., J. A. del Aguila, A. Marchi, J. C. Vera, E. L. Orionte, and A.E. BernaRdón. 1980. Manejo Racional de un Campo en la Región Arida de Los Llanos de La Rioja (in Spanish). Buenos Aires, Argentina: Instituto Nacional de Tecnología Agropecuaria. $90 \mathrm{p}$.

Bazán, 0. 1993. Información climática de 13 años del Campo Experimental "Las Vizcacheras" (in Spanish). Instituto Nacional de Tecnología Agropecuaria. La Rioja, Argentina: EEA La Rioja. 11 p.

Blanco, L., and C. FerRando. 2000. Evaluación de la técnica de estimación visual de la disponibilidad forrajera en pasturas de buffelgrass y en pastizales del Chaco Arido (in Spanish). Revista Argentina de Producción Animal 20(1):187-188.

Bozzo J. A., S. L. Beasom, and T. E. Fulbright. 1992. Vegetation responses to 2 brush management practice in south Texas. Journal of Range Management 30:70-175.

Cabido, A. L., A. Manzur, L. Carranza, and C. González Albarracín. 1994. La vegetación y el medio físico del Chaco Arido en la provincia de Córdoba, Argentina Central (in Spanish). Phytocoenología 24:423-460.

Daubenmire, R. 1959. A canopy-coverage method of vegetation analysis. Northwest Science 33:43-65.

Díaz Nieva, N., L. J. Blanco, and M. Guzmán. 1994. Delimitación de Zonas y Subzonas Pluviométricas de Los Llanos de La Rioja (in Spanish). Seminario de Titulación; 26 de Marzo de 1994; La Rioja, Argentina: Universidad Provincial de La Rioja. 33 p.

Ferrando, C. A., and P. NamuR. 1984. Resultados parciales obtenidos con la raza Criolla Argentina en el Campo Las Vizcacheras (in Spanish). Revista Argentina de Producción Animal 4(1):85-92.

Ferrando, C. A., L. Blanco, E. Orionte, F. Biurrun, D. Recalde, and P. Namur. 2001. Utilización de especies nativas por el ganado bovino en un ecosistema de Los Llanos de La Rioja (in Spanish). In: Resúmenes del Primer Congreso Nacional sobre Manejo de Pastizales Naturales. Santa Fé, Argentina: San Cristóbal. p 78-79.

FuLBRIGHT, T. E. 1996. Viewpoint: a theoretical basis for planning woody plant control to maintain species diversity. Journal of Range Management 49: 554-559.

FuLBRIGHT, T. E., AND S. L. BEASOM. 1987. Long term effect of mechanical treatment on white-tailed deer browse. Wildlife Society Bulletin 15:560-564.

Gómez, J. C., H. F. Calella, R. F. Corzo, and A. A. Reynoso. 1993. Mapa de Subregiones de Suelo y Vegetación del Chaco Arido de La Rioja (in Spanish). La Rioja, Argentina: Universidad Provincial de La Rioja, GTZ. 162 p.

Gómez, J. C., A. A. Reynoso, A. Ricarte, and E. Aguirre. 1998. Impacto del rolado sobre la dinámica de arbustos y la condición del pastizal natural (in Spanish). In: Resúmenes de la XVII Reunión Argentina de Ecología 21-23 Abril de 1998. Asociacion Argentina de Ecología. Buenos Aires, Argentina. p 54.

Gonź́lez, C. L., AND J. D. DodD. 1979. Production response on native and introduced grasses to mechanical brush manipulation, seeding, and fertilization. Journal of Range Management 32(4):305-309.

Ibarra-F, F. A., J. R. Cox, M. H. Martin-R, T. O. Crowl, and C. A. Call. 1995. Predicting buffelgrass survival across a geographical and environmental gradient Journal of Range Management 48:53-59.

Martin-R, M. H., J. R. Cox, and F. Ibarra-F. 1995. Climatic effects on buffelgrass productivity in the Sonoran Desert. Journal of Range Management 48:60-63.

Morello, J., L. A. Sancholuz, and C. A. Blanco. 1985. Estudio Macroecológico de Los Llanos de la Rioja (in Spanish). Buenos Aires, Argentina: Serie del Cincuentenario de la Administración de Parques Nacionales $53 \mathrm{p}$.

NamuR, P. 1985. Buffel grass: generalidades, implantación y manejo (in Spanish). Instituto Nacional de Tecnología Agropecuaria. La Rioja, Argentina: EEA La Rioja. $8 \mathrm{p}$.

Namur, P., E. Orionte, L. Blanco, A. Rettore, and M. Aguilera. 1998. Módulo experimental de un sistema de cria bovino extensivo mejorado (in Spanish). Revista Argentina de Producción Animal 18(1):255-256.

Passera, C. D., E. Borsetto, R. J. Candia, and C. R. Stasi. 1992. Shrub control and seeding influences on grazing capacity in Argentina. Journal of Range Management 45:480-482.

Pechanec J., and G. Pickford. 1937. A weight estimate method for the determination of range and pasture production. Journal of the American Society of Agronomy 29:894-904.

Pielou, E. C. 1966. The measurement of diversity in different types of biological collections. Journal of Theoretical Biology 13:131-144.

RAUNKIAER, C. 1934. The life forms of plants and statistical plant geography. Oxford, UK: Clarendon Press. 632 p.

SAS InSTITUTE. 1989. SAS/STAT user's guide. Version 6, 4th ed., Vol. 2. Cary, NC: SAS Institute Inc.

Schott, M., and R. Pieper. 1987. Succession of pinyon-juniper communities after mechanical disturbance in southcentral New Mexico. Journal of Range Management 40(1):88-94.

Scifres, C., W. Hamilton, J. Conner, J. Inglis, G. Rasmussen, R. Smith, J. Stuth, and T. WeLCH. 1985. Integrated brush management systems for South Texas: development and implementation. B-1493, College Station, TX: Texas Agricultural Extension Station.

Shannon, C. E., and And W. Weaver. 1949. The mathematical theory of communication. Urbana, IL: University of Illinois Press.

Tanner, G. W., J. M. Wood, R. S. Kalmbacher, and F. G. Martin. 1988. Mechanical shrub control on flatwoods range in south Florida. Journal of Range Management 41(3):245-248.

Wilm, H., D. Costello, and D. Klipple. 1949. Estimating forage yield by the double sampling method. Agronomy Journal 36:194-203.

YaRLETT, L. L. 1965. Control of saw-palmetto and recovery of native grasses. Journal of Range Management 18:344-345. 